
A
$\mathbf{R}$
T
$\mathbf{Y}$
$\mathbf{K}$
$\mathrm{U}$
$\mathbf{E}$

Joanna MaŁgorzata Sondel Cedarmas

Uniwersytet Jagielloński

\title{
OD 'NECESSITAS NON HABET LEGEM’ DO RACJI STANU. KILKA UWAG O REWOLUCJI W JĘZYKU POLITYKI W SZESNASTOWIECZNYCH WŁOSZECH
}

\section{WPROWADZENIE}

W XVI w. dokonała się istotna zmiana w sposobie pojmowania polityki, która znalazła wyraz również w terminologii politycznej. Włoski historyk doktryn politycznych Maurizio Viroli określił ową radykalną transformację jako „rewolucję polityki” (rivoluzione della politica) ${ }^{1}$. Nie ulega watpliwości, że w okresie odrodzenia nastąpiło odejście od średniowiecznej koncepcji arte politica - pojmowanej jako sztuka rządzenia państwem, której celem jest dobro wspólne - i przejście do doktryny racji stanu, czyli racji istnienia państwa, zakładającej jego naczelny interes oraz wiedzę dotyczącą środków utrzymania się u władzy². Zmiana ta niosła za sobą utratę prestiżu polityki: po okresie uznawania jej za „naczelną i najszlachetniejszą wsród nauk humanistycznych" zgodnie

1 M. Viroli, Dalla politica alla Ragion di Stato. La scienza del governo tra XIII e XVII secolo, Roma 1994, s. VII.

2 Jak zauważył Jacob Burckhardt, państwo renesansowe było postrzegane jako dzieło sztuki, wymagające specjalnych umiejętności (statecraft). Polityka stała się szkołą mężów stanu, uczącą, jak rządzić państwem. Por. J. BurckHARDT, Kultura odrodzenia we Włoszech, Warszawa 1999. 
z koncepcją Arystotelesa ${ }^{3}$, polityka jako dążąca do utrzymywania i poszerzania władzy za wszelką cenę oraz dzięki wszelkim możliwym środkom zaczęła objawiać się jako działalność podła, zdeprawowana i nieetyczna. Zjawisko to, chociaż w XVII w. przybrało charakter uniwersalny, zostało zapoczątkowane we Włoszech, w szczególnej sytuacji społeczno-polityczno-ekonomicznej szesnastowiecznej Italii, podzielonej na wiele małych, ustawicznie ze sobą konkurujących państw. Niewątpliwy wpływ w wykształceniu się nowego spojrzenia na rzeczywistość polityczną oraz nowożytny język polityczny wywarli humanistyczni florentcy pisarze polityczni - Niccolò Machiavelli oraz Francesco Guicciardini. Jak podkreślił krakowski filozof prawa Arkady Rzegocki, idee Machiavellego czy Guicciardiniego miały swoje historyczne źródła w politycznej niestabilności włoskich miast oraz w niezwykle okrutnych obyczajach towarzyszących zdobywaniu władzy lub tworzeniu nowych państw. Mnogość istniejących bytów politycznych w połączeniu z brakiem uświęconych tradycją dynastii powodowały, że drogę do książęcych tronów mieli otwartą niemal wszyscy - w pierwszym rzędzie bogaci i bezwzględni mieszczanie oraz kondotierzy ${ }^{4}$. Wiek XVI był też momentem, kiedy w wielu państwach na Półwyspie Apenińskim zaczęły kształtować się nowożytne formy życia politycznego, a do języka politycznego weszły takie pojęcia, jak Stato (państwo), virtù (cnota), fortuna (los), necessità (konieczność polityczna, „konieczność stanu”, „konieczność państwa”) oraz ragion di stato (racja stanu). Część tych wyrażeń miała znacznie starszą metrykę, wywodzącą się jeszcze z tradycji starożytnej, którą w dużej części przejeła średniowieczna myśl polityczna. W okresie odrodzenia nastąpiła jednak istotna modyfikacja

3 Arystoteles, Etyka Nikomachejska, tłum. D. Gromska, Warszawa 2002, s. 78.

4 W XV w. struktura polityczna Włoch uległa stabilizacji. W północnej części Półwyspu Apenińskiego powstały cztery państwa: Genua, Mediolan, Wenecja i Florencja, w środkowej - Państwo Kościelne, natomiast na południu - Neapol i Sycylia. Należy podkreślić, że komuny miejskie we Włoszech były w dużym stopniu tworami „sztucznymi”, tworzonymi przez ludzi, w przeciwieństwie do „naturalnych”, powstałych w sposób organiczny z innych państw-monarchii średniowiecza. Por. A. RzEgoCKI, Racja stanu a polska tradycja myślenia o polityce, Kraków 2008, s. 162-163, oraz K. Grzy bowski, Wstęp, [w:] M. Machiavelli, Książę, Wrocław-Warszawa-Kraków 1969, s. XXV. 
ich znaczenia w związku z próbą dostosowania języka do zmieniającej się rzeczywistości politycznej oraz społecznej. Celem niniejszego artykułu będzie przeanalizowanie najważniejszych pojęć wprowadzonych do języka politycznego przez Niccolò Machiavellego, a zarazem próba przedstawienia ich genezy, definicji znaczeniowej, a także recepcji w języku polskim. Nie ulega wątpliwości, że autor Księcia był inicjatorem nowego spojrzenia na politykę, jednak jego koncepcje polityczne pozostawały silnie zakorzenione w późnośredniowiecznej myśli florenckiej, nawiązującej do tradycji klasycznej. Stąd też kwestia jego wkładu w powstanie nowego języka polityki budzi pewne kontrowersje $e^{5}$. Nie ulega wątpliwości, że florencki prawnik był człowiekiem przełomu epok, świadkiem rozkładu starych średniowiecznych grup społecznych oraz transformacji wolnych komun miejskich z miasta - państwa w państwo „terytorialne”. Jak słusznie zauważył Konstanty Grzybowski, Europa Machiavellego, a w wyższym jeszcze stopniu Włochy Machiavellego to

5 Za ojca nowożytnej terminologii politycznej uważa Machiavellego Arkady Rzegocki, który stwierdził, że autor Księcia nie tylko wyodrębnił rozważania dotyczące mechanizmów politycznych z szerszego kontekstu, niezależnego od etyki, religii czy teologii i nadał im praktyczny oraz utylitarny charakter, ale stworzył także nową siatkę pojęć służących opisowi rzeczywistości politycznej. Odmiennego zdania byli natomiast tacy uczeni, jak Isaiah Berlin i Konstanty Grzybowski, a obecnie Maurizio Viroli, którzy wykazali, że florencki prawnik był raczej uczniem polityków oraz myślicieli późnośredniowiecznej i wczesnorenesansowej Florencji i dopiero po nim zmienił się język polityki. W opinii Grzybowskiego Machiavelli był zasadniczo spadkobiercą myśli republikańskiej, łączącej w sobie praktykę polityczną wolnych komun włoskich i jej teoretyczną konstrukcję oraz ideologiczne uzasadnienie za pomocą pojęć politycznych Rzymu republikańskiego i analogii historycznych do jego dziejów. Stąd operował on jeszcze konstrukcjami zaczerpniętymi z późnego średniowiecza. Stwierdzenie Grzybowskiego odpowiada przekonaniu Czesława Nankego, który podkreślił, że terminologia używana przez Machiavellego nie była jeszcze dokładnie sprecyzowana, ponieważ „nowożytne pojęcia polityczne kształtowały się dopiero tak, jak i nowożytne życie polityczne [...]. Terminologia starożytna już nie wystarczała, a nowa tworzyła się dopiero". Por. A. Rzegocki, Racja stanu a polska tradycja myślenia..., s. 173, a także K. Grzybowski, Machiavelli - człowiek Średniowiecza, [w:] A. Tomasık-Brzost, Niccolò Machiavelli - paradoksy losów doktryny, Warszawa 1973, s. 6; I. BERLIN, Oryginalność Machiavellego, [w:] Pod prąd, Poznań 2002, s. 151-157; C. NAnke, Wstęp, [w:] N. Machiavelli, Książę, Lwów-Warszawa 1920, s. XXXI. 
Europa i Włochy struktur w trakcie przekształcania się, jeszcze nieustabilizowanych i niebędących w stanie równowagi ${ }^{6}$. Ów brak równowagi polityczno-społecznej oraz próba znalezienia nowych wyrażeń lub nadania dawnym pojęciom nowego znaczenia, bardziej adekwatnego dla opisu zmieniającej się rzeczywistości, wyraźnie przebija w pismach politycznych florenckiego pisarza ${ }^{7}$. Należy zaznaczyć, że literatura na temat myśli politycznej i języka Machiavellego jest niezwykle bogata, stąd też niniejszy tekst, będący zasadniczo przyczynkiem do toczącej się od wielu lat dyskusji nad jego rzeczywistym nowatorstwem w wykształceniu się nowej idei oraz języka polityki, jest jednocześnie próbą usystematyzowania istniejącego stanu wiedzy.

\section{NicColò MaChiaVelli - TwóRCA NOWOŻYtNego JęZYKa POLITYKI?}

Pierwsze formy nowożytnej terminologii politycznej pojawiły się w komunach oraz republikach włoskich już w XIII w., a nowy język polityki kształtował się, czerpiąc z tradycji arystotelizmu, a także starożytnej myśli oraz prawa rzymskiego (uznawanego za civis sapientia). W trzynastowiecznych Włoszech, pod wpływem starożytnej tradycji polityczno-prawnej, a przede wszystkim koncepcji cnót obywatelskich z De re publica Cycerona i myśli stoików, ukształtowała się idea polityki jako „sztuki dobrych i sprawiedliwych rządów”, a także ideał „sprawującego rządy”, czyli tego, który posiada odpowiednie cnoty polityczne oraz broni wspólnoty obywatelskiej, gwarantując powszechny pokój

\footnotetext{
6 K. Grzy bowski, Machiavelli - człowiek Średniowiecza..., s. 6.

7 Należy zgodzić się ze stwierdzeniem Eugenio Garina, że pojęcie państwa w koncepcji Machiavellego, niezależnie od formy rządów - republikańskich czy monarchistycznych, dzięki stanowionym przez siebie prawom miało pozwolić na ucywilizowanie życia w sytuacji załamania dotychczasowych norm religijnych, moralnych i społecznych; E. GArin, Nad myślą Machiavellego, "Archiwum Historii Filozofii i Myśli Społecznej» 19/1973, s. 10-24.
} 
i sprawiedliwość8. Koncepcję bonum commune jako celu istnienia społeczności politycznej w pełni rozwinął już św. Tomasz z Akwinu. Doktor Anielski podkreślał, że pierwszym i naczelnym obowiązkiem męża stanu powinno być sprawowanie rządów według nakazów prawa i kierowanie się sprawiedliwością dla wspólnego dobra społeczności. Podobną definicję polityki jako sztuki rządzenia w oparciu o sprawiedliwość (in iustitia) i rozum (cum ratione) przedstawił też florencki pisarz i polityk Brunetto Latini w średniowiecznej encyklopedii pt. Skarbiec wiedzy (Livres dou Tresor) w $1266 \mathrm{r}$. Dla Latiniego, podobnie jak dla Arystotelesa, polityka pozostawała najważniejszą wśród nauk humanistycznych, a zarazem najszlachetniejszą działalnością człowieka, ponieważ uczyła rządzić poddanymi (królestwa, miasta czy komuny) zgodnie z rozumem i sprawiedliwością i to zarówno w czasie pokoju, jak i wojny, a ostatecznym celem rządzenia miało być dobro publiczne 9 . Średniowieczni myśliciele dużo uwagi poświęcali cnotom politycznym, jakie powinien mieć władca. We wczesnym średniowieczu ideał owych cnót został przedstawiony już przez św. Marcina z Bragi w dziele Formula vitae honestae, napisanym pomiędzy 570 a 579 r., a także w powstałym w latach 1145-1170 traktacie Moralium dogma philosophorum, w którym anonimowy autor, wyliczając pożądane cechy władcy, zaliczył do nich uczciwość, ostrożność, sprawiedliwość, siłę i umiarkowanie. Średniowieczni teoretycy polityki wśród cnót politycznych naczelną rolę przypisywali jednak sprawiedliwości. Przekonaniom tym dał wyraz na przykład autor traktatu Oculus pastoralis, który zwrócił uwagę, że głównym obowiązkiem sprawujacego rządy miało być dbanie o sprawiedliwość (servando iustitiam). Dla św. Tomasza z Akwinu osoba piastująca władzę powinna nie tylko wyróżniać się wśród innych wiedzą oraz sprawiedliwością, lecz także umieć wykorzystywać te cechy na korzyść społeczności. Jak pisał w Summa Teologiae „dzięki umiejętnościom i cnocie (virtutis) oraz tego rodzaju sprawnościom człowiek jest zdolny do piastowania danej godności. [...] W osobie piastującej jakąś godność

\footnotetext{
Ponowne odkrycie myśli Arystotelesa nastąpiło w XIII w, po przetłumaczeniu na łacinę Polityki w 1260 r. i Etyki Nikomachejskiej w 1240 r.

9 Cyt. za: M. Viroli, op. cit., s. 15.
} 
należy uznać jej stanowisko wobec innych oraz prawo rządzenia ( $g u$ bernationis officium $)^{10}$. W swoim postępowaniu władca winien kierować się rozwagą, spokojem i opanowaniem. Oprócz cnoty sprawiedliwości powinien posiadać cnotę roztropności, a w szczególności „roztropności kierowniczej”, dzięki której miał pozostać w „służbie dobru społecznemu”. W koncepcji Akwinaty owa „roztropność kierownicza (regnativa)”, którą posiadał „naczelnik”, podobnie jak cnota „podporządkowania się, będąca u obywateli" to nic innego jak "polityka, odnosząca się do gromady państwowej (multitudo unius civitatis)" ${ }^{11}$. Ideał polityka w znaczeniu sprawującego rządy, który gwarantuje pokój i sprawiedliwość, możemy znaleźć również w powstałym w latach 40. XIII w. dziele Liber de regimine civitatum napisanym przez historyka Giovanniego da Viterbo. Wspomniany autor podkreślał, że władca komuny powinien być sprawiedliwy, mądry i ostrożny, a w sztuce rządzenia - kierować się sprawiedliwością i umiarem (iustitia et quitate). Z kolei Idzi Rzymianin (Egidio Romano), w powstałym około 1280 r. traktacie De regimine principum libri III, stwierdzał, że władca winien stać przede wszystkim na straży prawa. Do opracowania średniowiecznej definicji polityki oraz zestawienia przymiotów, jakie powinien posiadać władca, przyczynił się także prawnik, autor słynnych komentarzy do Kodeksu Justyniańskiego (Commentari), Baldo degli Ubaldi (1327-1400), który podobnie jak cytowani wcześniej autorzy, wśród cnót koniecznych do rządzenia civitas na pierwszym miejscu wymieniał sprawiedliwość, określając ją jako królową cnót. Należy zaznaczyć, że ów średniowieczny prawnik, nawiązując do rzymskiej idei cnót politycznych, łączył koncepcję polityki z prawem, podkreślając, że celem prawa jest utrzymanie civitas, a polityka jest sztuką rządzenia według zasad sprawiedliwości. Z kolei wspólczesny Baldo prawnik, kanclerz republiki florenckiej w latach 1375-1406, Coluccio Salutati, autor humanistycznego manifestu polityki, pojmowanej jako „najwyższy wyraz ludzkiej racjonalności, tworzący warunki do obywatelskiego szczęścia”12, opracował ideał sprawującego rządy,

10 Sum. Theol., II-II, q. 102, a. 1 resp.

11 Sum. Theol., II-II, q. 50, a. 2, ad. 3 i q. 48, a. 1.

12 A. Rzegocki, Racja stanu a polska tradycja myślenia..., s. 167. 
którego działalność polityczna powinna koncentrować się na obronie wolności komuny czy republiki. Należy wspomnieć, że w XIII w., pod wpływem przyswojenia koncepcji Arystotelesa, rozumienie polityki zostało poszerzone na de civitate doctrina, obejmując różne formy rządzenia i odpowiednią konstrukcję polityczną. W konsekwencji centrum uwagi średniowiecznych pisarzy politycznych przesunęło się z osoby rządzącego, jego obowiązków i cnót do analizy różnych form rządów. W pełni koncepcję polityki już nie tylko jako nauki dobrego rządzenia (sprawiedliwych rządów), lecz także jako sztuki tworzenia i utrzymywania właściwej konstrukcji politycznej (ustroju) opracował Dante Alighieri w traktacie De Monarchia, powstałym w latach 1309-1313, gdzie przedstawił swoją koncepcję zjednoczenia Europy w postaci „monarchii uniwersalnej", pod przywództwem Cesarza Niemiec. Projekt Dantego ściśle wiązał się z kwestią, która szczególnie interesowała czternastowiecznych myślicieli i teoretyków polityki, a mianowicie zapewnienia trwałego pokoju w Europie. Autor Boskiej Komedii podkreślał, że pokój będący „najważniejszym dobrem i koniecznym warynkiem do zapewnienia szczęścia na ziemi” mógł być zapewniony jedynie przez politykę, ponieważ była ona źródłem i początkiem właściwych konstrukcji politycznych ${ }^{13}$. Dla większości późnośredniowiecznych myślicieli modelem politycznym pozostawał republikański Rzym i w konsekwencji najlepszą formą istnienia i rozwoju civitas miała być republika. Wśród zdecydowanych zwolenników ustroju republikańskiego należy wymienić florenckich teoretyków polityki, a w szczególności historyka i dyplomatę Leonarda Bruni czy wspomnianego już prawnika Colluccio Salutatiego, do których koncepcji nawiązywał też Niccolò Machiavelli ${ }^{14}$. Chociaż w powszechnym mniemaniu florencki pisarz uważany jest za zdecydowanego apologetę absolutnej monarchii, w rzeczywistości jednak jego

13 Por. D. Alighieri, De Monarchia, Kęty 2002, s. 35.

14 Jednak i tu można znaleźć wyjątki. Dla Idziego Rzymianina najlepszą formą rządów, żeby zagwarantować jedność wewnętrzną i pokój, miała być monarchia elekcyjna. Święty Tomasz opowiadał się natomiast za ustrojem mieszanym (commixtum), to znaczy takim, w którym występują zarówno elementy monarchistyczne, arystokratyczne, jak i demokratyczne. Por. J. Grzy Bowski, Filozoficzny uniwersalizm sporu o charakter władzy. Tomasz z Akwinu i Dante Alighieri, Kęty 2005, s. 3220-323. 
idealnym ustrojem pozostawał późnośredniowieczny republikański model florencki ${ }^{15}$. Dał temu wyraz w III księdze Rozważań nad pierwszym dziesięcioksiegiem historii Rzymu Liwiusza, gdzie pisał: „Republiki są bardziej trwałe od monarchii i dłużej dopisuje im szczęście; dzięki różnorodności usposobień swoich obywateli dostosowują się one łatwiej do zmiennych czasów"16. Warto zaznaczyć, że Machiavelli posługiwał się starożytnymi określeniami res publika lub republica, opisując za ich pomocą każdy ustrój działający w zgodzie z prawami oraz z systemem rządów opartym na wyborach władz. Florencki pisarz w swojej koncepcji republiki nawiązywał do koncepcji cnót obywatelskich z De officiis Cycerona oraz rozwoju i upadku republikańskiego Rzymu z Bellum Catilinae Salustiusza. Wzorując się z kolei na klasycznej koncepcji cykli przemian ustrojowych, wymienił trzy zasadnicze przyczyny zepsucia ustrojów: 1) bezczynność lub duchowa bierność społeczeństwa; 2) zbyt daleko posunięte nierówności społeczne, a w pierwszym rzędzie poniżanie i zniewolenie ludu oraz 3) tyrania czy „zbyt wielka władza rządzących"17. W odróżnieniu jednak od średniowiecznych teoretyków ustroju republikańskiego był zdania, że choć podstawą dobra wspólnego jest ład społeczny, nie musi być on tożsamy ze spokojem, zgodą i harmonią, lecz może być wynikiem wewnętrznych napięć i konfliktów. Wyraźnie przedstawił to w IV księdze I części Rozważań, stwierdzając, że w każdej republice istnieją dwa stronnictwa: ludu oraz możnych i „z niezgody między tymi dwoma stronnictwami rodzą się wszelkie prawa zabezpieczające wolność” ${ }^{\prime 18}$. Machiavelli wyróżnił także właściwe

15 Jak wykazał Mieczysław Maneli, chociaż w Księciu Machiavelli wydaje się popierać rozwiązanie absolutystyczne, to jednak tendencje i sympatie republikańskie są wyraźne w powstałych w tym samym okresie Rozważaniach nad pierwszym dziesięcioksięgiem historii Rzymu Liwiusza. Dzieło to ukazało się drukiem już po śmierci Florentczyka w 1531 r., ale zostało napisane w latach 1513-1519. Por. M. MANeLI, Machiavelli, Warszawa 1968, s. 54.

16 Por. N. Machiavelli, Rozważania nad pierwszym dziesięcioksieggiem historii Rzymu Liwiusza, Warszawa 2009, s. 285.

17 Por. P. ŚpIewak, Wstęp, [w:] N. Machiavelli, Rozważania nad pierwszym dziesięcioksięgiem historii Rzymu Liwiusza..., s. I.

18 N. Machiavelli, Rozważania nad pierwszym dziesięcioksięgiem historii Rzymu Liwiusza..., s. 24. 
oraz niewłaściwe formy rządów, zaliczając do pierwszej kategorii monarchię, arystokrację i demokrację, natomiast do drugiej - tyranię, oligarchię i anarchię. Florencki pisarz nie był zasadniczo zwolennikiem dyktatury, podkreślając, że jednostka lub grupa sprawująca władzę powinna dbać przede wszystkim o interesy ogółu. Nie zgadzał się jednak z twierdzeniem, że to instytucja dyktatury umożliwiła Juliuszowi Cezarowi przejęcie tyrańskiej władzy i spowodowała upadek republiki rzymskiej, wykazując, że doprowadziło do tego raczej jej wadliwe stosowanie. W sytuacji nagłego niebezpieczeństwa zalecał powrót do formy jednowładztwa, gdyż - jak podkreślał - gdy trzeba walczyć z wrogiem, musi być jeden wódz naczelny, któremu przysługuje pełnia władzy. Z taką właśnie sytuacją mamy do czynienia w Księciu. Konstanty Grzybowski słusznie zauważył, że Machiavelli wykreował w ten sposób mit „prowizorycznego monokraty”, na wzór dyktatora rzymskiego, który po „odnowieniu republiki”, wraca w szeregi zwykłych obywateli i nie ma tym samym prawa dokonywać jakichkolwiek zmian w ustroju republiki ${ }^{19}$.

Podobnie jak średniowieczni teoretycy polityki, florencki sekretarz dużo uwagi w swoich pismach politycznych poświęcił osobie władcy i jego virtù. Definicja pojęcia virtù, kluczowego w doktrynie makiawelizmu, podobnie jak jego etymologia, stała się przedmiotem licznych sporów współczesnych politologów, historyków oraz językoznawców i do dziś jest przedmiotem różnych, często przeciwstawnych interpretacji. Chociaż wszyscy badacze są zasadniczo zgodni, że pojęcie to nie ma nic wspólnego z chrześcijańskim pojmowaniem cnoty, kwestią sporną pozostaje, czy florencki prawnik nawiązał tu do tradycji klasycznej. Dla historyka Czesława Nanke, autora jednego z pierwszych tłumaczeń Księcia na język polski, pojęcie to odpowiada rzymskiemu virtus i oznacza „siłę ducha, moc, energię lub kulturę duchową i materialną”, a nawet, w szczególnych przypadkach „cnotę w znaczeniu etycznym”20. Starorzymską tradycję pojęcia virtù odrzucił zdecydowanie Leo Strauss,

19 K. Grzybowski, Machiavelli - człowiek Średniowiecza..., s. 78, i K. Prokop, Modele stanu nadzwyczajnego, Białystok 2012, s. 66.

20 N. Machiavelli, Książę, przeł. i oprac. C. NANke, Lwów-Warszawa 1920, s. 24. 
podkreślając, że w twórczości Machiavellego nastąpiło odejście od klasycznej cnoty politycznej Platona, Arystotelesa czy Cycerona ${ }^{21}$. Jakikolwiek związek virtù Machiavellego z zasadami moralności zanegowali z kolei Mieczysław Maneli oraz Romuald Piekarski, którzy zwrócili uwagę, że w naszkicowanym przez Florentczyka idealnym ustroju nie ma miejsca na sprawiedliwośćc ${ }^{2}$. Zbieżność do rzymskiego pojęcia antiqua virtus dostrzegł natomiast Arkady Rzegocki, w opinii którego virtù autora Księcia oznacza „męstwo, wewnętrzną siłę, wolę walki, przedsiębiorczość, aktywność, ambicję i siłę woli”23. Nie ulega wątpliwości, że w doktrynie machiavellizmu mamy do czynienia ze swoistym dualizmem zastosowania tego pojęcia. Jak słusznie zauważył Konstanty Grzybowski, w okresie odrodzenia pojawiły się dwa nowe pierwiastki wpływające na definicję virtù, a mianowicie dynamizm oraz relatywizm. Z jednej strony myśl Machiavellego opierała się na przekonaniu, że nie ma niezmiennie dobrych i niezmiennie złych metod rządzenia ludźmi, są tylko metody adekwatne do zaistniałej sytuacji i metody nieadekwatne, z drugiej virtù była ściśle powiązana z pojęciem fortuny, to znaczy splotem okoliczności, które mogą wpłynąć zarówno na losy męża stanu, jak i całego państwa ${ }^{24}$. Stąd zdaniem Romualda Piekarskiego, który określił virtù jako „wyjątkowe i nadzwyczajne kwalifikacje” pozwalające na kontrolowanie fortuny, pojęcie cnoty przedstawione w Księciu nie jest sprzeczne ze starorzymskim virtus czy starogreckim arete. Jak podkreślił wspomniany filozof polityki, inaczej będą wyglądać relacje pomiędzy fortuna a virtù w przypadku władcy, który dysponuje silnym wojskiem, a jeszcze inaczej u monarchy dziedzicznego ${ }^{25} . \mathrm{Na}$ ścisły związek pomiędzy cnotą męża stanu i fortuną zwróciła także

21 Por. L. Strauss, Machiavelli's Intention: The Prince, «The American Political Science Review» 51.1/1951, s. 34-38.

22 Por. M. Maneli, Historia doktryn politycznych i prawnych, część I, Warszawa 1961, s. 27-28; R. PIEKARSKi, Koncepcja cnót politycznych Machiavellego na tle elementów klasycznej etyki cnót, Gdańsk 2007.

23 A. Rzegocki, Racja stanu a polska tradycja myślenia..., s. 174.

24 K. Grzybowski, Historia doktryn politycznych i prawnych, Warszawa 1968, s. 263-264.

25 R. Piekarski, op. cit., s. 125. 
uwagę historyczka literatury Anna Klimkiewicz, która określiła pojęcie virtù jako wyznacznik doskonałej władzy, a zarazem „właściwość umysłu, która pozwala na rozpoznanie konkretnych sytuacji, jak i siłę decyzji, męstwo i cnotę polityczną". W tym sensie virtù może być cechą zarówno jednostek, jak i warstw rządzonych w społeczeństwie, może wskazywać na dzielność i rozum, ale także na „zdolność symulacji”. W opinii Klimkiewicz, chociaż pojęcie to nawiązuje do virtus starożytnych, w znaczeniu „cnoty czynu, męstwa, odwagi, honoru, myśli i sławy”, to jednak podporządkowuje się jednej wartości nadrzędnej, a mianowicie „zdolności utrzymania władzy”. Stąd w nowo powstającym języku politycznym wspomniana „cnota” jest postrzegana w perspektywie użyteczności względem państwa i jest synonimem tych wszystkich wartości, które powinien posiadać władca, aby utrzymać państwo, przynieść mu korzyści i zapewnić jego funkcjonowanie ${ }^{26}$. Pojęcie virtù może odnosić się zarówno do osoby lub grupy sprawującej władzę, jak i do twórcy państwa. Należy tutaj podkreślić, że Machiavelli bardzo dużo uwagi poświęcił kwestii budowania nowych państw, rozróżniając ich dwa rodzaje: 1) takie, które powstały dzięki virtù ich twórcy, oraz 2) principato civile, to znaczy księstwa obywatelskie, powstałe „Z woli ludu”. Niewątpliwie nowatorstwo florenckiego pisarza polegało nie tyle na wprowadzeniu samego pojęcia Stato do literatury politycznej, gdyż występowała ona już w średniowiecznych traktatach politycznych, ile na nadaniu mu nowego, współczesnego znaczenia. Amerykański historyk niemieckiego pochodzenia Felix Gilbert zwrócił uwagę, że w traktatach politycznych w XV w. termin ten był często używany na określenie „sprawującego władzę”, jak na przykład „państwo Medyceuszy”, więc zasadniczo odnoszony do panującego wraz z jego dworem lub danej, ściśle określonej „przestrzeni geograficznej” (np. stato di Firenze). Machiavelli używa natomiast terminu stato (państwo) w czterech różnych znaczeniach: 1) w odniesieniu do narodu lub wspólnoty politycznej; 2) pisząc o ustroju politycznym lub formie rządu, na przykład „stato libero” („wolne państwo”); 3) na określenie władzy politycznej lub 4) terytorium, nad którym książę czy republika sprawują władzę. Jak słusznie

26 Por. A. Klimkiewicz, Wstęp, [w:] N. Machiavelli, Ksiq̨żę, Kraków 2005, s. 8-9. 
zauważyła Barbara Markiewicz, w średniowieczne pojęcie państwa wpisane było znamienne dla struktur feudalnych powiązanie władzy i własności ziemi decydujące o politycznej niezależności. U Machiavellego mamy natomiast wyraźnie do czynienia z procesem oddzielenia tych pojęć, co było charakterystycznym symptomem procesu modernizowania się Europy ${ }^{27}$. U sekretarza florenckiego pojęcie to ma więc charakter uniwersalny, oznaczając „niezależną wspólnotę polityczną”, mogącą przybierać różne formy ustrojowe (republiki lub monarchii), które decydują o strukturze władzy. Można więc powiedzieć, że pojęcie to pojawia się we współczesnym znaczeniu, czyli jako „to wszystko, co składa się na organizm polityczny" ${ }^{28}$. Świadczy o tym wyraźnie pierwszy akapit w I rozdziale Księcia, gdzie Machiavelli przedstawia powiązania pomiędzy różnymi formami ustrojowymi: „Tutti li stati, tutti e dominii che hanno avuto et hanno imperio sopra li uomini, sono stati e sono o republiche o principati" ${ }^{29}$. Niezależnie od wspomnianego nowatorstwa terminu należy jednak podkreślić za Konstantym Grzybowskim, że państwo u Machiavellego jest jeszcze raczej identyczne z władcą (status id est magistratus), a istotny atrybut władzy suwerennej (princeps est legibus solutus), który występuje już na przykład u Bodina, nie jest jeszcze dla florenckiego sekretarza koniecznym i trwałym jej atrybutem, lecz jest ograniczony jedynie do sytuacji wyjątkowych (e' necessario a un principe $)^{30}$.

27 B. Markiewicz, Państwo albo stan, czyli o podstawie nowożytnej formy polityki, [w:] Państwo jako wyzwanie, red. A. Rzegocki, Kraków 2000, s. 28.

28 F. Gilbert, Machiavelli e Guicciardini. Pensiero politico e storiografia a Firenze nel Cinquecento, Torino 2012, s. 122.

29 Należy zaznaczyć, że w polskich tłumaczeniach to pojęciowe nowatorstwo uległo zatarciu. U Czesława Nankego brzmi to następująco: „Wszelkie państwa, wszelkie formy rządów, które miały lub mają władzę nad ludźmi, bywają republikami albo księstwami” (N. Machiavelli, Książę..., s. 31). Podobnie też daleko idącego uproszczenia dokonał Wincenty Rzymowski, który oddał to zdanie: „wszystkie państwa, wszystkie władztwa, które sprawowały i sprawują rządy nad ludźmi” (M. MACHIAVELLI, Książę, przeł. z włoskiego i przedmową opatrzył W. Rzyмowski, Warszawa 1917, s. 3), a także Mieczysław Manelli, tłumacząc: „wszystkie państwa, wszelkie polityczne organizacje, które miały lub mają władzę nad ludźmi” (M. MANELI, Machiavelli, s. 119).

30 K. Grzybowski, Machiavelli - człowiek Średniowiecza..., s. 80 


\section{OD NECESSITAS NON HABET LEGEM DO RACJI STANU}

Machiavelli uważany jest za twórcę nowożytnej doktryny racji stanu, chociaż jak wiadomo, sam nie posługiwał się tym pojęciem ${ }^{31}$. U florenckiego sekretarza teoria ragion di stato opierała się zasadniczo na średniowiecznej koncepcji necessitas, to znaczy sytuacji wyjątkowej, w której można działać wbrew prawu, oraz nawiązywała do starożytnej zasady ratio publicae utiltas czy ratio status, czyli przyczyny, dla której to działanie jest usprawiedliwione ${ }^{32}$. Jak zauważył Maurizio Viroli, chociaż samo pojęcie racji stanu było używane przez średniowiecznych i wczesnohumanistycznych pisarzy politycznych w znaczeniu cycerońskiego recta ratio, niemniej występowało ono w trochę innym znaczeniu, niż czynił to Machiavelli. W tradycji starożytnej „prawy rozum” przysługiwał temu, kto rządził sprawiedliwie, w oparciu o prawo, a pojęcie ratio status miało legitymizować lub usprawiedliwiać działania, które $\mathrm{w}$ innych okolicznościach zostałyby uznane za godne potępienia. Nie ulega wątpliwości, że koncepcja necessitas stanowi obok virtù i fortuna kluczową kategorię w doktrynie machiavellizmu. Jak słusznie zauważył Konstanty Grzybowski, punktem wyjścia do zrozumienia tej idei u Machiavellego jest charakterystyczne dla średniowiecza rozróżnienie dwóch rodzajów konieczności, rozwiniętych przez Tomasza z Akwinu: 1) konieczności „naturalnej, czyli absolutnej” oraz 2) „konieczności celu, która także nazywa się użytecznością". Na gruncie kanonistyki rozróżnienie to służyło do uzasadnienia papieskiego prawa dyspenzacji, a więc do postępowania sprzecznego $\mathrm{z}$ regułą, $\mathrm{z}$ normą prawną mającą w sytuacjach normalnych zastosowanie do danego przypadku ${ }^{33}$. To kanoniści jako pierwsi sięgnęli do reguły necessitas legem non habet wywodzącej się z prawa rzymskiego i w ten sposób otwarli drogę do

31 Pierwszym, który posłużył się tym terminem w nowożytności, był arcybiskup Giovanni della Casa w liście do cesarza Karola V w 1525 r.

32 Koncepcję tę przedstawił nie tyle nawet w Księciu, ile w Rozważaniach nad pierwszym dziesięcioksięgiem historii Rzymu Liwiusza. Por. M. VIroli, op. cit., s. IX.

33 Ibidem, s. LIII-LIV. 
podobnych koncepcji na terenie państwa ${ }^{34}$. Należy jednak podkreślić, że średniowieczni kanoniści ograniczali granicę dyspenzacji do prawd wiary (odnoszących się do rzeczy pozaziemskich) oraz do podstawowych zasad ustroju Kościoła, czyli „kościelnej racji stanu”. Zgodnie z tą koncepcją normy prawne miały zastosowanie w „sytuacjach normalnych", podczas gdy w sytuacjach, gdy wymagała tego norma wyższego rzędu, w szczególności status ecclesiae, przez którą należy rozumieć utrzymanie istnienia Kościoła i jego podstawowych zasad - można, a nawet powinno się działać wbrew nim. W konsekwencji - jak zauważył Grzybowski - sytuacje nienormalne były traktowane przez kanonistów średniowiecznych nie wedle „etyki pryncypialnej”, lecz wedle kryteriów „etyki sytuacyjnej”, a więc zasadniczo sprzecznej z zasadami współżycia społecznego, obowiązującymi dla „sytuacji normalnych”. Podobnie też pojęcia necessitas, utilitas publica, salus populi odnosiły się do nadrzędnych zasad współżycia społecznego. Już w średniowieczu uznawano, że w sytuacjach krytycznych interes państwa stoi ponad interesami i prawami prywatnymi, podczas gdy dla sytuacji normalnych prawa prywatne były granicami tego, co określano jako utilitas publica ${ }^{35}$. Chociaż Machiavelli przejął w koncepcji necessitas zasady późnośredniowiecznej filozofii moralnej, kanonistyki i nauki o państwie, poszedł jednak o krok dalej. W jego koncepcji, jeśli istnieje sytuacja wyjątkowa i władca działa w celu jej przezwyciężenia, żeby umożliwić przez to powrót do sytuacji „normalnej”, wówczas może działać sprzecznie z prawem. Nowatorstwo Machiavellego polega także na dopuszczeniu sytuacji, w której władca działa dla zdobycia władzy (więc w celu wychodzącym poza średniowieczny model „stanu konieczności”), kiedy rezultatem jego działania ma być korzystna dla społeczeństwa stabilizacja stosunków ${ }^{36}$. Nie ulega wątpliwości, że w takim przypadku florencki pisarz w swojej koncepcji necessitas wyszedł poza średniowieczne granice rozumienia konieczno-

34 Tego samego zdania był niemiecki badacz Friedrich Meinecke, który stwierdził, że kres starożytnego rozumienia racji stanu, wywodzącej się z tradycji rzymskiej, położyło pojawienie się uniwersalistycznej religii chrześcijańskiej. Por. F. MEınecke, Die idee der Staatsräson in der neuren Geschichte, München 1963, s. 30.

35 K. Grzybowski, Wstęp..., s. LIV-LV.

36 Ibidem, s. LVI. 
ści, które zakładało, że można działać wbrew powszechnie przyjętym zasadom i normom jedynie w momencie istniejącego niebezpieczeństwa. W koncepcji Machiavellego władca może stosować gwałt lub postępować z okrucieństwem, jeśli celem tego działania jest dobro państwa i ogółu, na przykład żeby zagwarantować „bezpieczeństwo oraz powiększyć dobro poddanych”. To, co wyróżnia myśl Machiavellego, to wyraźne odseparowanie sfery politycznej od etyki. Jak stwierdził wyraźnie w Rozważaniach nad pierwszym dziesięcioksięgiem historii Rzymu Liwiusza: „Kiedy chodzi bowiem o ocalenie ojczyzny, nie wolno kierować się tym, co słuszne lub niesłuszne, litościwe lub okrutne, chwalebne lub sromotne. Nad wszystko inne zważać należy wtedy na to, aby zapewnić jej przetrwanie i uratować jej wolność" ${ }^{37}$. W tym sensie polityka skuteczna staje się dobra, a nieskuteczna - zła. Aby być skutecznym, władca musi podejmować w interesie państwa decyzje trudne. W sytuacji wyższej konieczności (necessità) może on złamać dane słowa, zerwać ustalenia traktatu, a nawet uwięzić lub zamordować kogoś, kto mógłby zagrozić bezpieczeństwu i stabilności państwa. Zasadnicza różnica w koncepcji necessitas u Machiavellego w porównaniu z teoretykami średniowiecza polegała także na tym, że owa „konieczność” nie ma charakteru krótkotrwałego i niepowtarzalnego. U Machiavellego sytuacja wyjątkowa może mieć charakter trwały, wynikając ze szczególnej sytuacji w dziejach państwa, kiedy takie działanie jest uzasadnione. Jak zauważył Arkady Rzegocki, władca może działać w sytuacji niemal permanentnego stanu wyjątkowego, w którym stosowanie środków nadzwyczajnych przestaje być właściwie ograniczane ${ }^{38}$. Osobną kwestią do rozstrzygnięcia pozostaje natomiast sytuacja, gdy sprawujący władzę działa nie w interesie ogółu, lecz dla korzyści osobistych. Należy tutaj podkreślić, że u Machiavellego, zarówno w Księciu, jak i w Rozważaniach nad dziesięcioksięgiem Tytusa Liwiusza - księga I cel utrzymania się przy władzy nie jest jeszcze „koniecznością”, jeśli nie jest identyczny z interesem państwa, lecz wynika z interesu prywatnego panującego. Podobnie

37 N. Machiavelli, Rozważania nad pierwszym dziesięcioksięgiem historii Rzymu Liwiusza..., s. 254.

38 A. Rzegocki, Racja stanu a polska tradycja myślenia..., s. 112. 
też zasada niestosowania reguł moralnych jest ograniczona jedynie do sytuacji związanych z funkcjonowaniem państwa. Z koniecznością i prawem postępowania wbrew przyjętym zasadom możemy mieć do czynienia dopiero w sytuacji, gdy trzeba odeprzeć niebezpieczeństwo zagrażające państwu, zapewnić pokój i bezpieczeństwo obywateli, a nie zagwarantować jedynie utrzymania się u władzy panującego.

Zarysowaną przez Machiavellego koncepcję racji stanu rozwinął w pełni inny florencki teoretyk polityki Francesco Guicciardini w Dialogo del Reggimento di Firenze, napisanym w latach 1521-1525, gdzie wymienił on czyny godne potępienia z punktu widzenia moralności, lecz uzasadnione interesem państwa. Guicciardini jeszcze wyraźniej niż Machiavelli wprowadził rozróżnienie pomiędzy dawną ideą polityki rozumianą jako sztuka zachowania res publiki, w znaczeniu wspólnoty jednostek żyjących razem zgodnie z zasadami sprawiedliwości, oraz nową - pojmowaną jako zdolność przetrwania państwa, w sensie utrzymania pojedynczej lub grupowej władzy i kontroli publicznych instytucji. Florencki historyk w Ricordi politici e civili wyraził też w pełni ideę oddzielenia moralności od polityki, podkreślając, że „nie można utrzymać państwa zgodnie z sumieniem” („Non si può tenere stati secondo coscienza”), natomiast w II Księdze Dialogo del Reggimento di Firenze doradzał stosowanie radykalnych czy wręcz okrutnych środków wobec nieprzyjaciół, łącznie z oddaniem w niewolę czy zamordowaniem jeńców wojennych. Jak zauważył Alessandro Passerin d'Entrèves, to za sprawą Guicciardiniego, bardziej jeszcze niż Machiavellego, dokonało się definitywne przejście od idei polityki jako szlachetnej sztuki rządzenia według zasad sprawiedliwości i rozumu do koncepcji „racji stanu, w znaczeniu wiedzy dotyczącej środków zachowania dominacji nad ludźmi”"39.

39 A. Passerin d’Entrèves, Dante politico e altri saggi, Torino 1955, s. 159. 


\section{O RECEPCjI RaCji StANU W EUROPEJSKiej MYŚLI POLITyCZNEJ}

Należy zaznaczyć, że doktryna racji stanu szesnastowiecznych, florenckich pisarzy politycznych wyraźnie różniła się od idei innych współczesnych im teoretyków polityki. W szczególności do diametralnie odmiennego wniosku w porównaniu z Machiavellim i Guicciardinim doszedł Erazm z Rotterdamu, który w Institutio principis christiani, rozważając kwestię, czy można obronić królestwo bez pogwałcania prawa, podkreślał, że nie należy robić nic, co mogłoby zaszkodzić sprawiedliwości, a kwestią nadrzędną dla władcy powinno być dbanie o przestrzeganie prawa wewnątrz państwa i kierowanie się zasadami sprawiedliwości w działalności politycznej zgodnie z zasadą fiat iustitia, ruat caelum ${ }^{40}$. Koncepcje Machiavellego, chociaż spotkały się też z krytyką większości ówczesnych humanistów, zwłaszcza angielskich i francuskich, którzy oskarżali go o niszczenie wszelkich cnót oraz legitymizowanie działań nieetycznych, zaczęły zdobywać uznanie w Europie w XVII w. ${ }^{41}$ Wyraźnie świadczy o tym traktat flamandzkiego filozofa i historyka Justusa Lipsiusa pt. Politicorum sive civilis doctrinae libri sex, który w 1594 r. wyraźnie wziął w obronę teorię Machiavellego, podkreślając, że „w czasach gwałtów i nienawiści jest rzeczą oczywistą, że każdy książę, który chce przeżyć, musi nauczyć się mieszać to, co jest dla niego korzystne, z tym, co jest

40 Q. Skinner, Le origini del pensiero politico moderno, I: Il Rinascimento, Bologna 1989, s. 401-402.

41 Teorie polityczne Machiavellego jako legitymizujące wszelkie działanie władzy, które prowadzi do profitu, a także „perwersyjne i destabilizujące” porządek publiczny zostały skrytykowane m.in. przez francuskiego prawnika Innocentego Gentilleta w dziele Anti-Machiavel w 1576 r. oraz hiszpańskiego jezuitę Pedro de Ribadeneyra $\mathrm{w}$ traktacie Tratado de la religion y virtudes que deue tener el Principe Christiano, który w 1595 r. podkreślił, że obowiązkiem władcy jest postępowanie według zasad chrześcijańskich i dbanie o nienaruszanie prawa boskiego i religii. Zwolennikiem nieco mniejszego rygoru moralnego w działalności politycznej był natomiast francuski pisarz i filozof Guillaume Budé, który w dziele De l'institution du Prince w 1547 r., chociaż poświęcił dużo uwagi przestrzeganiu „cnoty sprawiedliwości” przez władców, zalecał im jednocześnie kierowanie się przede wszystkim ostrożnością w rządzeniu państwem. Szerzej na ten temat por. Q. SKInNER, op. cit., s. 406. 
szlachetne” ${ }^{\text {"2 }}$. Próbę połączenia „racji interesu państwowego” z moralnością chrześcijańską podjął natomiast Giovanni Botero w dziele Della Ragion di Stato, które ukazało się drukiem w 1589 r. Jak pisał ów włoski jezuita: „jeśli przez państwo rozumie się trwałe panowanie nad ludem, to racja stanu oznacza znajomość środków umożliwiających ustanowienie, zachowanie i umocnienie tak rozumianego zwierzchnictwa i panowania"43. W koncepcji Botero racja stanu oznaczała zasadniczo znajomość środków mających na celu założenie, utrzymanie i poszerzenie państwa, przy założeniu, że fundamentem państwa pozostają cnoty księcia, wśród których naczelną rolę odgrywa sprawiedliwość, zapewniająca powszechny pokój oraz zgodę. Utrzymanie państwa zależało jednak od zdolności władcy do zachowania reputacji w oczach poddanych, jak i innych państw. Jan Malarczyk zauważył, że u Botero celem władzy państwowej musi być realizacja zasady „dobra publicznego” (bene pubblico), to znaczy „dobra władzy”, a zarazem dobra i pomyślności poddanych”44. W celu zapewnienia trwałości państwa władca powinien zapewnić sobie miłość poddanych dzięki takim cnotom, jak męstwo, wielkość umysłu oraz przede wszystkim sprawiedliwości. Należy zaznaczyć, że włoski myśliciel przyznawał szczególną rolę w państwie religii katolickiej i Kościołowi. Jak podkreślał, dzięki nim umacnia się władza panującego, wspierana „nadprzyrodzoną pomocą miłosierdzia Boskiego”, a religia jest „fundamentem każdego państwa, wszelka bowiem władza pochodzi od Boga, łaskawości którego nie można zaskarbić inaczej niż poprzez zachowanie przykazań religii”45.

42 Jeszcze wyraźniej koncepcję ragion di stato Machiavellego poparł angielski prawnik Stephen Gardiner w traktacie A Discourse on the Coming of the England and Normans to Britain, napisanym w latach 1553-1555, który podkreślał, że władca w oczach poddanych powinien uchodzić za cnotliwego i sprawiedliwego, lecz „kiedy jest to konieczne, żeby utrzymać władzę w państwie, musi umieć postępować wbrew zasadom religii, wiary i litości”. Podobnie też w 1590 r. francuski pisarz Guillaume Du Vair uzasadniał, że w sytuacji najwyższej konieczności władca powinien dążyć przede wszystkim do utrzymania państwa. Ibidem.

43 Por. G. Botero, Della region di stato. Con tre libri delle cause della grandezza della città, red. L. Firpo, Torino 1948, Dedica, s. 1.

44 Por. J. Malarczy , Idea „racji stanu” w myśli politycznej Renesansu włoskiego, [w:] Racja stanu. Historia, teoria, współczesność, red. E. Olszewski, Lublin 1989, s. 20.

45 G. Botero, op. cit., s. 93. 
Dzieło Botera cieszyło się wielką popularnością w siedemnastowiecznej Europie, prowadząc do legitymizacji pojęcia racji stanu. Jak stwierdził Arkady Rzegocki, głównie za sprawą jezuickiego myśliciela pod koniec XVI w. w Hiszpanii pojawiło się rozróżnienie na „dobrą” i „złą razon de Stato". Zgodnie z koncepcją Pedro de Ribadeneyra, przedstawioną $\mathrm{w}$ traktacie Tratado de la religion y virtudes que deue tener el principe christiano para gouernar y conseruar sus estados w 1595 r., dobra racja stanu wynikała $\mathrm{z}$ dawnej tradycji, gdzie religia i normy etyczne odgrywały kluczową rolę, natomiast zła manifestowała się w momencie, gdy interes państwa lub władcy stawał się najwyższym celem, któremu miały być podporządkowane wszystkie inne normy ${ }^{46}$. Zdaniem Rzegockiego w polskiej tradycji politycznej ze względu na przywiązanie do wymiaru etycznego w ocenie działań politycznych przez długi czas nie przyjęła się dominująca w Europie Zachodniej od początku XVII w. koncepcja polityki, wywodząca się od Machiavellowskiej racji stanu. Aż do końca XVIII w. nawiązywano raczej do tradycji klasycznej, przekazanej przez Botero i hiszpańską dobrą rację stanu. Podobnie też samo pojęcie nie cieszyło się szczególną popularnością w Polsce, gdyż uważano je za legitymizację absolutyzmu lub przynajmniej uzasadnienie wszelkich poczynań władzy ${ }^{47}$. Taką interpretację można znaleźć na przykład w słowach siedemnastowiecznego pisarza politycznego, sekretarza króla Zygmunta III Wazy, Pawła Piaseckiego, który pisał: „ «Rarum decus in terris» pan w jednowładztwie wstrzemięźliwy. A tym więcej tych czasów nieszczęsnych, kiedy wymyślili sobie słówko (musi je położyć tym językiem, w którym się urodziło) 'radzion del Stato'. To już gdzie jedno mogą mieć pokrywkę, wszystkie prawa, wszystkie wolności, wszystkie przysięgi, na stronę iść

46 Dzieło Botera zostało bardzo szybko przetłumaczone na hiszpański. Ukazało się drukiem już w 1593 r. pt. Diez libros de la razon de Estado. Zarówno w Hiszpanii, jak i Portugalii bardzo krytycznie odnoszono się do pism Machiavellego. Świadczy o tym traktat portugalskiego pisarza Jerónimo de Osorio, De Nobilitate Christiana, opublikowany w latach 40. XVI w., a także wspomniane już dzieło Pedro de Ribadeneyra. Por. A. Rzegocki, Racja stanu a polska tradycja myślenia..., s. 137-138.

47 Ibidem, s. 105. 
muszą. Najwyższe to u nich prawo «suprema lex», nie tylko ludzkie, ale i boskie prawa temu ustępować muszą" ${ }^{38}$. Zmiana podejścia do racji stanu nastąpiła w Polsce w okresie zaborów, kiedy dla narodu pozbawionego własnej państwowości naczelnym celem, uświęcającym wszelkie środki, stało się odzyskanie niepodległości ${ }^{49}$. Stąd również w dziewiętnastowiecznej Polsce uznanie potrzeb i dobra kraju za najwyższy obowiązek sprawiło, że polskie pojęcie wpisało się w nowożytną tradycję teorii ragione di stato, zapoczątkowaną przez florenckich myślicieli politycznych w szesnastowiecznych Włoszech. Wyraźnie do tej koncepcji nawiązał już kilka lat po odzyskaniu niepodległości Stanisław Grabski, który w 1925 r. stwierdził: „Polska racja stanu to wskazanie rozumu, oparte na doświadczeniu historycznym, a wypływające $\mathrm{z}$ naturalnego prawa i obowiązku narodu polskiego - utrzymania zabezpieczenia od jakiegokolwiek uszczerbku odzyskanego dziedzictwa państwowego"50. Należy zaznaczyć, że pod względem etymologicznym w polskim pojęciu „racji stanu”, które zasadniczo odpowiada „racji państwa”, przetrwała włoska wersja lo stato. Jak wiadomo, polskie słowo „państwo”, w przeciwieństwie do większości języków zachodnioeuropejskich, nie wywodzi się z języka włoskiego, chociaż słowo „stan”, stanowiące dokładny odpowiednik włoskiego lo stato, funkcjonowało przez pewien czas pod koniec XVIII w. ${ }^{51}$ Ostatecznie

48 R. Skowron, Spory o racje stanu, antymakiawelizm $w$ Polsce $i w$ Hiszpanii w XVI i XVII wieku, [w:] Spory o państwo w dobie nowożytnej. Między racja stanu a partykularyzmami, red. Z. ANUsıK, Łódź 2007, s. 354.

49 Jak wykazał Arkady Rzegocki, jednym z pierwszych, który zaczął odwoływać się do pojęć „racja stanu” czy raison d’état był Maurycy Mochnacki, który twierdził, że sprawa świadomości narodowej, sprawa „uznania się w jestestwie swoim” - zrozumienia, kim się jest, stanowi punkt wyjścia każdego ambitnego przedsięwzięcia. Por. A. Rzegocki, Racja stanu w polskiej tradycji politycznej, [w:] Kryterium etyczne w koncepcji Racji Stanu, red. A. KrzynóweK-Arndt, Kraków 2013 s. 43.

50 S. GrabsKi, Z zagadnień polityki narodowo-państwowej, Warszawa 1925, s. 25.

51 Słowo „stan” możemy znaleźć na przykład w pierwszym tłumaczeniu Szymona Bielskiego traktatu Kanta Do wiecznego pokoju w 1797 r., gdzie niemieckie słowo der Staat zostało przetłumaczone jako „stan”. Prawdopodobnie w języku polskim słowo „stan” zostało wyparte za sprawą konieczności tłumaczenia dokumentów sporządzonych w języku rosyjskim. 
jednak zostało ono wyparte w okresie zaborów przez wywodzący się z języka rosyjskiego termin „państwo" ${ }^{2}$.

\section{ZAKOŃCZENIE}

Chociaż nie ulega wątpliwości, że idee polityczne Machiavellego wyrastały ze średniowiecznej myśli politycznej, jednak w swojej koncepcji państwa oraz doktryny racji stanu zapoczątkował on nowożytną naukę państwa i prawa. Jego nowatorstwo w stosunku do klasycznego myślenia o polityce polegało z jednej strony na oddzieleniu celów czysto politycznych od moralności oraz religii i co za tym idzie, na emancypacji nauki o polityce, a z drugiej na stworzeniu zespołu pojęć charakterystycznych dla nowożytnego języka politycznego. Florencki pisarz w swojej koncepcji virtù czy necessitas czerpał niewątpliwie z tradycji starożytnej i dzięki jego pośrednictwu wspomniane pojęcia weszły, w nowym znaczeniu, do współczesnej terminologii politycznej. Za sprawą Machiavellego przetrwanie i rozwój państwa stały się najważniejszymi celami podejmowanych działań, a kluczowe dla tradycji klasycznej pojęcie dobra wspólnego zostało zastąpione przez pojęcie interesu państwa. Innymi słowy, bazująca na średniowiecznej idei necessitas racja stanu zastąpiła kategorię etyczną dobra wspólnego, a podstawowym kryterium działań politycznych oraz oceny funkcjonowania państwa stała się już nie idea sprawiedliwości, harmonii czy dobrego życia, lecz skuteczność. Stąd można zgodzić się z twierdzeniem, że w XVI w. we Włoszech Machiavelli

52 Polskie słowo „państwo”, które etymologicznie wywodzi się od słów „pan”, „panowanie”, zostało wprowadzone dopiero u progu XIX w. pod wpływem języka rosyjskiego. W Polsce na określenie państwa czy władzy państwowej początkowo używano łacińskich wyrażeń status regalis (stan królewski), status principis (stan książęcy), regnum Polonorum lub posługiwano się polskim „Korona” czy „Królestwo". Równolegle funkcjonowało też określenie dominum. Od XVI w. popularność zdobyło słowo Rzeczpospolita” będące tłumaczeniem łacińskiego Res Publica (rzecz wspólna). Słowo pan istniało jedynie u Słowian zachodnich, było natomiast zupełnie nieznane na Rusi i na Bałkanach. Dopiero od XV w. „pan” zastąpił słowo „gospodzina”, oznaczając „urzędnika chana awarskiego, pobierającego daniny”. Szerzej na ten temat por. B.A. MARKIEWICZ, op. cit., s. 29-32. 
zapoczątkował rewolucję w sposobie pojmowania polityki, stając się jednocześnie inicjatorem nowożytnego języka politycznego.

\section{OD 'NECESSITAS NON HABET LEGEM' DO RACJI STANU. \\ KILKA UWAG O REWOLUCJI W JĘZYKU POLITYKI \\ W SZESNASTOWIECZNYCH WŁOSZECH}

\section{Streszczenie}

Artykuł przedstawia wkład Niccolò Machiavellego w wykształcenie nowożytnej idei oraz języka polityki. Poprzez analizę kluczowych pojęć wprowadzonych do języka politycznego przez florenckiego myśliciela, autorka stara się udowodnić tezę, że chociaż wyrastał on ze średniowiecznej tradycji myśli politycznej, jednak opracowana przez niego idea państwa oraz racji stanu dały początek nowożytnej teorii państwa i prawa. W odróżnieniu od średniowiecznych teoretyków polityki, w myśli Machiavellego przetrwanie i rozwój państwa stały się najważniejszymi celami podejmowanych działań, a kluczowe dla tradycji klasycznej pojęcie dobra wspólnego, zostało zastąpione przez pojęcie interesu państwa. Podobnie też podstawowym kryterium działań politycznych oraz oceny funkcjonowania państwa stała się już nie idea sprawiedliwości, harmonii czy dobrego życia, lecz skuteczność.

From 'Necessitas non habet legem' to 'Raison d'Etat':

Some Remarks on the Revolution

IN The Language of Politics IN $16^{\text {TH }}$-Century Italy

\section{Summary}

The article presents Niccolò Machiavelli's contribution to the development of the modern concept and language of politics. I embark on an analysis of the key concepts Machiavelli brought into the language of politics to show that his view of the state and raison d'état gave rise to the modern theory of the state and law, even though he had been nurtured on the medieval tradition of political thought. Unlike the 
medieval theoreticians of politics, Machiavelli put special emphasis on the endurance and growth of the state, making them the primary objectives of political activity and replacing the common good - the concept which was the cornerstone of the classical tradition - with the concept of raison d'état. For him the basic criterion for the assessment of political action and the way the state worked was no longer the concept of justice, harmony or the good life, but effectiveness.

Słowa kluczowe: Niccolò Machiavelli; język polityki; państwo; virtù; necessitas; racja stanu.

Keywords: Niccolò Machiavelli; the language of politics; the state; virtù; necessitas; raison d'état.

\section{Literatura}

Berlin I., Oryginalność Machiavellego, [w:] Pod prąd, Poznań 2002.

Botero G., Della region di stato. Con tre libri delle cause della grandezza della città, red. L. Firpo, Torino 1948.

Burckhardt J., Kultura odrodzenia we Włoszech, Warszawa 1999.

Dante Alighieri, De Monarchia, Kęty 2002.

Chabod F., Scritti sul Rinascimento, Torino 1967.

De CaprariIs V., Francesco Guicciardini dalla politica alla storia, Napoli 1993. GARIN E., Nad myślą Machiavellego, "Archiwum Historii Filozofii i Myśli Społecznej» 19/1973, s. 10-24.

Gilbert F., Machiavelli e Guicciardini. Pensiero politico e storiografia a Firenze nel Cinquecento, Torino 2012.

Grabski S., Z zagadnień polityki narodowo-państwowej, Warszawa 1925.

Grzy воwsкi j., Filozoficzny uniwersalizm sporu o charakter władzy. Tomasz z Akwinu i Dante Alighieri, Kęty 2005.

Grzy воwsкi K., Wstęp, [w:] M. Machiavelli, Książę, Wrocław-Warszawa-Kraków 1969.

Grzy bowsкi K., Machiavelli - człowiek Średniowiecza, [w:] Niccolò Machiavelli-paradoksy losów doktryny, red. A. TomAsıк-BRzost, Warszawa 1973, s. 71-82.

Klimkiewicz A., Wstęp, [w:] N. Machiavelli, Książę, Kraków 2005.

Łuszczyńska M., 'Ubi ratio, ibi ius'. Doktryna prawna św. Tomasza z Akwinu, Lublin 2013.

Nanke C., Wstęp, [w:] N. Machiavelli, Książę, Lwów-Warszawa 1920. 
Passerin d'Entrèves A., Dante politico e altri saggi, Torino 1955.

Machiavelli N., Książę, przeł. i oprac. C. Nanke, Lwów-Warszawa 1920.

Machiavelli N., Książę, przeł. z włoskiego i przedmową opatrzył W. RzYMOWSKi, Warszawa 1917.

Machiavelli N., Książę, tłum. A. Klimkiewicz, Kraków 2005.

Machiavelli N., Rozważania nad pierwszym dziesięcioksięgiem historii Rzymu Liwiusza, Warszawa 2009.

Meinecke F., Die idee der Staatsräson in der neuren Geschichte, München 1963. MALARCZyK J., Idea „racji stanu” w myśli politycznej Renesansu włoskiego, [w:] Racja stanu. Historia, teoria, współczesność, red. E. Olszewski, Lublin 1989.

Maneli M., Historia doktryn politycznych i prawnych, część I, Warszawa 1961. Maneli M., Machiavelli, Warszawa 1968.

Markiewicz B.A., Państwo albo stan, czyli o podstawie nowożytnej formy polityki, [w:] Państwo jako wyzwanie, red. A. Rzegocki, Kraków 2000.

Passerin d'Entrèves A., Dante politico e altri saggi, Torino 1955.

PiekARSki R., Koncepcja cnót politycznych Machiavellego na tle elementów klasycznej etyki cnót, Gdańsk 2007.

Pвокор K., Modele stanu nadzwyczajnego, Białystok 2012.

RzEGocki A., Racja stanu a polska tradycja myślenia o polityce, Kraków 2008.

RzEGocki A., Racja stanu w polskiej tradycji politycznej, [w:] Kryterium etyczne w koncepcji Racji Stanu, red. A. KrZynóweK-ARndt, Kraków 2013, s. 37-52.

Skinner Q., Le origini del pensiero politico moderno, I: Il Rinascimento, Bologna 1989.

Skowron R., Spory o rację stanu, antymakiawelizm $w$ Polsce $i w$ Hiszpanii w XVI i XVII wieku, [w:] Spory o państwo w dobie nowożytnej. Między racja stanu a partykularyzmami, red. Z. ANusik, Łódź 2007, s. 339-355.

Strauss L., Machiavelli's Intention: The Prince, «The American Political Science Review» 51.1/1951, s. 34-38.

Tomasz z Akwinu, Suma teologiczna, II-II, q. 47-56: Roztropność, XVII, tłum. i oprac. ks. S. BE£CH, Londyn 1964; Suma teologiczna, II-II, q. 57-80: Sprawiedliwość, XVII, tłum. i oprac. F.W. BednarsKi OP, Londyn 1970; Suma teologiczna, II-II, q. 101-122: Cnoty społeczne, XX, tłum. i oprac. F.W. BEDNARSKi OP, Londyn 1972.

Viroli M., Dalla politica alla Ragion di Stato. La scienza del governo tra XIII e XVII secolo, Roma 1994. 